\title{
Behavior of Malaysian iGeneration in Purchasing Life Insurance Policy
}

\author{
Nooriha Abdullah", Azreen Roslan, Rosmi Yuhasni Mohamed Yusuf, \\ Mohd Faizol Rizal Mohd Rasid
}

Centre of Economic and Finance, Faculty of Business and Management, Universiti Teknologi MARA, Malaysia

Received August 8, 2020; Revised October 25, 2020; Accepted December 30, 2020

\section{Cite This Paper in the following Citation Styles}

(a): [1] Nooriha Abdullah, Azreen Roslan, Rosmi Yuhasni Mohamed Yusuf, Mohd Faizol Rizal Mohd Rasid, "Behavior of Malaysian iGeneration in Purchasing Life Insurance Policy," Universal Journal of Accounting and Finance, Vol. 8, No. 4, pp. 153 - 160, 2020. DOI: 10.13189/ujaf.2020.080408.

(b): Nooriha Abdullah, Azreen Roslan, Rosmi Yuhasni Mohamed Yusuf, Mohd Faizol Rizal Mohd Rasid (2020). Behavior of Malaysian iGeneration in Purchasing Life Insurance Policy. Universal Journal of Accounting and Finance, 8(4), 153 160. DOI: 10.13189/ujaf.2020.080408.

Copyright $\bigcirc 2020$ by authors, all rights reserved. Authors agree that this article remains permanently open access under the terms of the Creative Commons Attribution License 4.0 International License

\begin{abstract}
Globally the role of insurance industry is crucial for every country as it plays a core function in the mordern economy and the financial systems. Insurance, like other financial services, has become important due to the increase of risks and uncertainties in most societies. Simultaneously, the rapid changes in technology have a huge impact on human lives, in particular the internet. Since iGeneration or commonly known as Generation Z, includes people born between 1990s and early 2000s, was born 'in the internet' era, therefore most of their decision to buy things depends on the info that is obtained from the internet. With less than 40 percent of Malaysian citizens that own a life insurance or family takaful policy, there is a significant, untapped potential for the insurance industry to penetrate Malaysian market in particular the iGeneration population. Hence, this paper is to determine the drivers of consumer purchase behavior that can influence the willingness of iGeneration to buy life insurance policy. Due to the characteristic of iGeneration, a survey via 'google form' was utilized in order to obtain the relevant data. Using quantitative research method, about 200 questionnaires were distributed. The findings show that service quality variables of insurance company as well as perceived value of life insurance policy have significant effect on iGeneration behavior in purchasing life insurance policy. Whereas, the role of agent has no significant effect on the dependent variable of iGeneration behavior. Subsequently, perceived value of life insurance policy was found to be the most influential factor that affects
\end{abstract}

iGeneration behavior in purchasing life insurance policy. Thus, this paper suggests that iGeneration are aware about the benefits of purchasing life insurance products because iGeneration already have knowledge about life insurance policy and they can compare which insurance products are more valuable and worth to purchase. The implication towards the insurance companies as a catalyst of financial system in Malaysia, should grab this opportunity to enhance their marketing efforts to capture the potential buyers among the iGeneration.

Keywords iGeneration Behavior, Life Insurance Policy, Service Quality, Perceived Value, Insurance Agents

\section{Introduction}

Insurance has a role to play in ensuring the life, health and pension needs of society are met in a sustainable manner. This is because, the world's population is ageing and Malaysia is in the pipeline. Nevertheless, in Malaysia currently the millennials and iGeneration are expecting significant technological innovations in the entire chain of insurance operations. They believe in the future instead of the present and the desire to have a better and more secure future. Life insurance has its own value in terms of 
minimizing risks and uncertainties that help individuals save money while protecting against any personal risk such as their health or personal assets. Therefore, iGeneration need to be aware of the fact that they are better off being insured than being left uninsured as life insurance policy is important to be purchased for their future.

Based on the statistics shown by the Life Insurance Association of Malaysia (LIAM) in 2011, only $42 \%$ of Malaysian population is insured regardless of the type of insurance coverage they have meanwhile, $58 \%$ of the population is still uninsured. This is because, majority are very reluctant to allocate a portion of their funds aside for life insurance investment. They also failed to see the advantages and importance of having any type of insurance as a personal risk management tool. Hence, it is essential for an individual to be well aware of the importance of being insured in today's society in order to avoid unforeseen circumstances that could have severe impact in their life [26].

Insurance is one of the pillars of the nation's economy and it is thus imperative for the insurance industry to improve its services. Customer satisfaction is important in service sector and services can become the basis of the competition [10]. According to [20] and [29], majority of iGeneration encompass of children and teens that were born 'in the internet' era and are defined by their love of electronic communication, technology and media use. Hence, can insurance companies' services match the iGeneration expectation of quality services and high perceived value of life insurance which, are able to attract them towards purchasing life insurance policy? Apart from the above, is the role of agent vital in relation to iGeneration behavior towards purchasing life insurance policy?

\subsection{Objective of Study}

The main objective of this paper was to determine the factors that affect iGeneration behavior in purchasing life insurance policy in Malaysia.

\subsection{Hypothesis of Study}

The hypothesis of the study can be constructed as follows:

$\mathrm{H}_{1}$ : Service quality of insurance company has significant effect towards iGeneration behavior in purchasing life insurance policy.

$\mathrm{H}_{2}$ : Perceived value of life insurance policy has significant effect towards iGeneration behavior in purchasing life insurance policy.

$\mathrm{H}_{3}$ : Role of agent has significant effect towards iGeneration behavior in purchasing life insurance policy.

\section{Literature Review and Conceptual Framework}

\subsection{Literature Review}

Attribution theory is concerned with how ordinary people explain the causes of behavior and events. As defined by [7], "attribution theory deals with how the social perceiver uses information to arrive at causal explanations for events. It examines what information is gathered and how it is combined to form a causal judgment". This theory is much related to the behavior of iGeneration, who are made up of digital natives that seek information via digital devices, which [3] alleges for whom a life without the ever-present connectedness of digital devices can be difficult to imagine.

Referring to [18] observation, the amount of time that iGeneration in America spend on smartphones doubled between 2013 and 2016 to over five hours per day. However, currently teens are found to spend on average roughly nine hours a day using screen-based media, majority using mobile devices. This indicates that iGeneration spend more time on their smartphone compared spending their time with their families and friends, or doing any other activities. Thus, iGeneration are naturals with technology and can simultaneously use their phone to purchase any products or services. [22] studies, iGeneration turn to social media first to learn about new products or services before purchasing them. iGeneration will only be interested and follow products or services that represent their ideals, which majority are willing to share info online and expect an organization to use the same method when communicating with them. Therefore, insurance companies/ agents should use the data that iGeneration willingly share on social media such as interests, hobbies, music, sports, to name a few as an advantage when personalizing communiques with iGeneration.

According to [2] analysis statistic, there are 85,494 registered life insurance agents and 42,698 family Takaful agents serving 26 conventional insurance companies and 5 Takaful operators respectively. The role played by these insurance agents is vital in linking between the policyholders and the insurance company. As such, in this world of internet usage, the methods used by the insurance agents in approaching the iGeneration should be different from the traditional way of face to face. According to a report generated by [22], about $81 \%$ of iGeneration use social media as a resource to purchase a product. Meanwhile, [22] also believe that the internet and social media make the world a more even playing ground for all participants, without cultural, linguistic, or economic barriers. Therefore, it is vital for insurance agents to strategically utilize advertisements via social media in promoting their insurance products, so that iGeneration are constantly stimulating and inundated with content from 
multiple sources. Nevertheless, referring to an 'Agency Theory', [11] and [17] noted that an agent is a decision maker with incurring a little or no risk at all because any losses that occurred will be borne by the principle as an agent work on principle behalf. Thus, could insurance agents provide a quality services that could meet the high expectation of iGeneration? This is crucial, because the satisfaction of iGeneration towards purchasing life insurance policy could be based on the services performed by these insurance agents.

iGeneration, as informed earlier are the generation of future, where cost of living in Malaysia has also increased since the last 20 years. This scenario highlighted the value of acquiring proper financial management scheme that will enable the Malaysian citizen to enjoy the retirement year comfortably. Empirical studies revealed that there is lack of understanding and awareness in relation to having life insurance. Since year 2014, there has been an increase in fees for medical consultation and procedures in Malaysia, which indicates the importance for an individual to be insured, regardless of whether it is through conventional life insurance or Takaful [31]. Therefore, life insurance policy should be purchased by iGeneration that need to be protected as well as be assisted in future. However, it may be quite difficult to persuade iGeneration to buy life insurance policy, if they perceived that the insurance coverage has no or having less value.

According to [28] and [32], perceived value is considered as the customer's overall evaluation of a product/service value, based on the perception of what is received and what is given. According to [5] and [8], perceived value is regarded as the determinant of customers' satisfaction. If the customers experience any unexpected sentiments after purchasing the products/services, this will affect the perceived value of that products/services. Thus, most customers expect to receive benefits that are greater than the cost. Meanwhile, [15], noted that perceived value can represent marketing, promotion, and classifying market in a better way because, consumers' perception is a proper resource to develop services. Hence, utilizing developed and moderated criterions of a perceived value perception allows insurers to compare various products and plans values to their advantage, as well as identifies the dimensions of perceived value as positive and negative characteristics of their products and services. With regards to the earlier scenario, iGeneration can also compare which products are more valuable and worth to purchase.

\subsection{Conceptual Framework of the Study}

Empirical evidences from previous studies have discussed some factors that could affect or have influences on the buying behaviors of general public in purchasing any products/services, which were mentioned above. Nevertheless, this paper studies on the effect of service quality of insurance company, perceived value of life insurance and role of agent (as the independent variables), on the iGeneration behavior (as the dependent variable) in purchasing life insurance policy in Malaysia as shown in Figure 1 below.

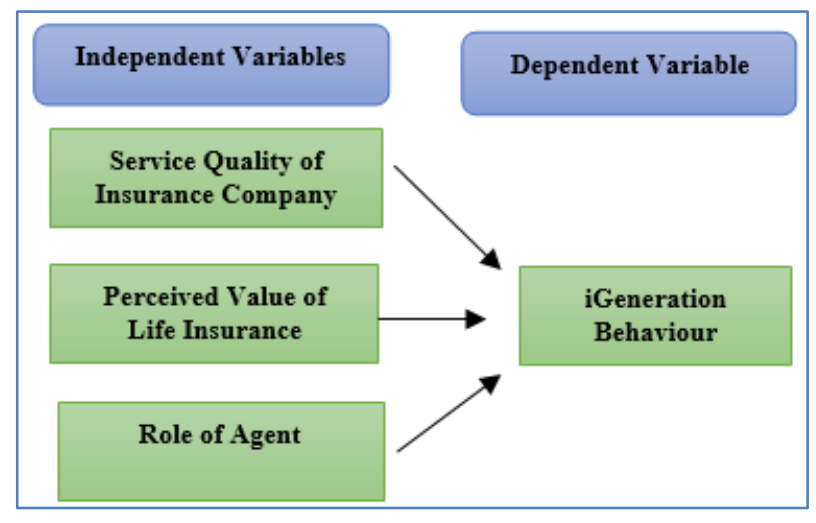

Figure 1. Conceptual Framework

\section{Methods}

The purpose of this study was to assess the relationship between service quality of insurance company, perceived value of life insurance and role of agent with iGeneration behavior with regards to purchasing life insurance policy in Malaysia. The conceptual framework contains three hypotheses to be tested in determining the relationship between the variables. For that purpose, the researchers have distributed a questionnaire to 200 iGeneration in Malaysia which, age ranges between 21 to 28 years old. The questionnaire contained four sections which, focus on the demographic profiling, iGeneration behavior, service quality of insurance company, perceived value of life insurance policy and role of agent.

The questionnaires were distributed via 'google form' as it matches the characteristic of iGeneration that were born in the 'internet era'. However, a pilot study was conducted on ten iGeneration in order to evaluate feasibility, time, cost, adverse events, and improve upon the study design prior to performance of a full-scale research. A quantitative research design is used in this research as it is more appropriate with the purpose of this study. Hence, a primary data collection method was utilized to obtain the relevant data. Meanwhile, secondary data such as books, websites, blogs, articles and journals assist the researchers with useful information to describe the theories and models to support the data in this research paper.

Utilizing Statistical Package for Social Science (SPSS) version 25 , the researchers analyzed the collected data by using Descriptive Analysis, Person's Correlation Coefficient and Regression Analysis. The Descriptive Analysis was used for easy understanding the demographic profile of iGeneration that participate in this research, as well as to measure the central tendency of mean of each question in the research [23] and [33]. Meanwhile, 
Person's Correlation Coefficient was used to measure the power and correlation link between one dependent variable to another which, this research examined the correlation between iGeneration behavior and service quality of insurance company, perceived value of life insurance and role of agent. As for Regression Analysis, it was used to determine percent of dependent variable on the independent one as well as measuring the hypothesis to determine the independents variables significant effect towards the dependent variables [4] and [23]. The findings of the research are discussed in the next section.

\section{Findings}

\subsection{Reliability Test}

To determine the reliability of the data from the survey, the data set has to undergo the Cronbach's Alpha test. The questionnaire has been providing responses using the Likert scale which covers the range from strongly disagree, disagree, slightly disagree, agree and strongly agree. These scales are crucial to assess a one-dimensional factor. Meanwhile, the questions utilized in this survey remain consistent. There were correlations in the scores derived from the survey. Using SPSS, the variability found in individual scores was tested. The alpha $(\alpha)$ values in the reliability test are mostly above 0.914 . These show that the results of the questions asked in the survey demonstrated a high internal consistency. Only one item on dependent variable that demonstrates a good result with alpha $(\alpha)$ value of 0.793 . The result of the analysis is depicted in Table 1, where " $N$ " indicates the total number of questions asked to each participant of the survey and the respective corresponding value obtained.

Table 1. Reliability statistics. Cronbach's Alpha value

\begin{tabular}{|c|c|c|}
\hline Items & Cronbach's Alpha & N number of items \\
\hline $\begin{array}{c}\text { Service Quality of } \\
\text { Insurance Company }\end{array}$ & 0.917 & 10 \\
\hline $\begin{array}{c}\text { Perceived Value of } \\
\text { Life Insurance } \\
\text { Policy }\end{array}$ & 0.194 & 10 \\
\hline Role of Agent & 0.939 & 10 \\
\hline $\begin{array}{c}\text { iGeneration } \\
\text { Behavior }\end{array}$ & 0.793 & 10 \\
\hline
\end{tabular}

\subsection{Descriptive Analysis}

Employing a descriptive analysis, the mean and standard deviation for the interval scaled items are obtained. They are described, examined and summarized as the main features of data collected via quantitative approach.. Besides, using this analysis, the variance for the interval scaled between independent variables and dependent variable is also obtained. Below is the description of the overall mean and standard deviation for dependent variables and independent variables.

\subsubsection{Respondents Demographic Profile Analysis}

The demographic analysis of the 200 respondents reveals that majority of the respondents come from the age between 23 to 24 which is $45.5 \%$. As for the gender, $69.5 \%$ were female respondents. The percentage of the respondents' races shows that Malay (72\%), Chinese $(16.5 \%)$ and Indian (11.5\%). As for their education background, $74.5 \%$ were degree holder, $16.5 \%$ were Diploma holder, while, $6.5 \%$ only had Sijil Tinggi Malaysia (SPM) and the balance $2.5 \%$ were from Master holder. Lastly, the demographic analysis shows $58.5 \%$ of the respondents do not own life insurance policy while $41.5 \%$ of the respondents own life insurance policy. The reason majority of the respondents do not own life insurance policy is because most of them are students, internship students or fresh graduates, who do not earn any income yet.

\subsubsection{Mean and Standard Deviation Analysis}

To measure the central tendency and dispersion of the items in the questionnaires, mean and standard deviation is used. Table 2 below shows the summary of Descriptive Statistic Analysis of mean and standard deviation of the variables. The descriptive output shows that all the independent variables were tapped on a 6.00-point scale. From the results, it may be seen that the mean for all the variables is about average that is Service Quality of Insurance Company (467.15\%) Perceived Value of Life Insurance Policy (472.25\%), Role of Agent (478.75\%) and iGeneration Behavior $(467.70 \%)$ on a 6-point scale, which indicate that the iGeneration behavior towards these variables are relatively moderate in purchasing life insurance policy in Malaysia.

Table 2. Summary of Descriptive Statistic Analysis

\begin{tabular}{|c|c|c|c|c|}
\hline Variables & Min. & Max. & Mean & $\begin{array}{c}\text { Standard } \\
\text { Deviation }\end{array}$ \\
\hline $\begin{array}{c}\text { Service Quality of } \\
\text { Insurance } \\
\text { Company }\end{array}$ & 2.60 & 6.00 & 4.6715 & 0.67223 \\
\hline $\begin{array}{c}\text { Perceived Value of } \\
\text { Life Insurance } \\
\text { Policy }\end{array}$ & 2.80 & 6.00 & 4.7225 & 0.65689 \\
\hline Role of Agent & 2.40 & 6.00 & 4.7875 & 0.71516 \\
\hline $\begin{array}{c}\text { iGeneration } \\
\text { Behavior }\end{array}$ & 2.80 & 6.00 & 4.6770 & 0.57979 \\
\hline
\end{tabular}

\subsection{Analysis of Correlation}

With regard to the correlation analysis, the relationship that exists between two or more quantifiable variables is being determined and to what its extent is. The results are as follows: 
Table 3. Correlation of the variables

\begin{tabular}{|c|c|c|c|}
\hline & & $\begin{array}{l}\text { Service Quality } \\
\text { of Insurance } \\
\text { Company }\end{array}$ & $\begin{array}{c}\text { iGeneration } \\
\text { Behavior }\end{array}$ \\
\hline \multirow[t]{4}{*}{$\begin{array}{l}\text { Service Quality } \\
\text { of Insurance } \\
\text { Company }\end{array}$} & $\begin{array}{c}\text { Pearson } \\
\text { Correlation }\end{array}$ & 1 & 0.546 \\
\hline & $\begin{array}{c}\text { Sig. } \\
\text { (2-tailed) }\end{array}$ & & 0.000 \\
\hline & $\mathrm{N}$ & 200 & 200 \\
\hline & & $\begin{array}{c}\text { Perceived Value } \\
\text { of Life Insurance } \\
\text { Policy }\end{array}$ & $\begin{array}{c}\text { iGeneration } \\
\text { Behavior }\end{array}$ \\
\hline \multirow[t]{4}{*}{$\begin{array}{c}\text { Perceived } \\
\text { Value of Life } \\
\text { Insurance } \\
\text { Policy } \\
\end{array}$} & $\begin{array}{c}\text { Pearson } \\
\text { Correlation }\end{array}$ & 1 & 0.576 \\
\hline & $\begin{array}{c}\text { Sig. } \\
\text { (2-tailed) }\end{array}$ & & 0.000 \\
\hline & $\mathrm{N}$ & 200 & 200 \\
\hline & & Role of Agent & $\begin{array}{c}\text { iGeneration } \\
\text { Behavior }\end{array}$ \\
\hline \multirow[t]{3}{*}{ Role of Agent } & $\begin{array}{c}\text { Pearson } \\
\text { Correlation }\end{array}$ & 1 & 0.465 \\
\hline & $\begin{array}{c}\text { Sig. } \\
\text { (2-tailed) }\end{array}$ & & 0.000 \\
\hline & $\mathrm{N}$ & 200 & 200 \\
\hline
\end{tabular}

**.Correlation is significant at the 0.01 level (2-tailed)

With reference to Table 3 above, it shows the first aim is to examine the relationship between Service Quality of Insurance Company with iGeneration behavior. The coefficient value, $r=0.546$, that indicates moderate positive correlation with Service Quality of Insurance Company. The second aim is to examine the relationship between Perceived Value of Life Insurance Policy with iGeneration behavior which, has a coefficient value, $r=0.576$, that also shows moderate positive correlation with Perceived Value of Life Insurance Policy. In the final aim, it is to examine the relationship between Role of Agent with iGeneration behavior. It has a coefficient value, $\mathrm{r}=0.465$, which indicates low positive correlation with Role of Agent.

\subsection{Multiple Regression Analysis}

The multiple regression test is an extension of bivariate correlation. It represents the best predicted to the dependent variable from several independent variables. The regression analysis is used to measure the percentage of dependent variables that can be explained by the independent variable.

Table 4. Model Summary

\begin{tabular}{|c|c|c|c|}
\hline Model & Adjusted R2 & R Square & $\begin{array}{c}\text { Durbin } \\
\text { Watson }\end{array}$ \\
\hline 1 & 0.359 & 0.369 & 1.815 \\
\hline
\end{tabular}

A model summary displayed on Table 4 shows that a multiple regression analysis was employed to evaluate Service Quality of Insurance Policy, Perceived Value of
Life Insurance Policy and Role of Agent. From the table, the R2 indicates the percentage variance in the dependent variable. It is explained by the variation in the independent variables. Here R2 shows that approximately $36.9 \%$ of the variance in dependent variable represents the factors affecting iGeneration behavior, which can be explained by the three factors of independent variables as explained above. Another $63.1 \%$ of the variance in the dependent variable is not explained by these independent variables. It indicates that there are other independent variables which are not included in this study.

Table 5. ANOVA

\begin{tabular}{|c|c|c|}
\hline Model & F & Significant \\
\hline 1 & 38.159 & 0.000 \\
\hline
\end{tabular}

From Table 5 above, the result of ANOVA, shows the significant value is 0.000 which estimates the value $p>$ 0.05 . All the independent variables significantly explained the dependent variable. This can be interpreted by the regression analysis as being normal and the hypothesis can be accepted in this study.

Table 6. Coefficient for Independent Variables and Dependent Variables

\begin{tabular}{|c|c|c|c|c|c|}
\hline \multirow{2}{*}{ Model } & \multicolumn{2}{|c|}{$\begin{array}{c}\text { Unstandardized } \\
\text { Coefficients }\end{array}$} & $\begin{array}{c}\text { Standardized } \\
\text { Coefficients }\end{array}$ & \multirow{2}{*}{ T } & Significant \\
\cline { 2 - 5 } & $B$ & $\begin{array}{c}\text { Std. } \\
\text { Error }\end{array}$ & Beta & & \\
\hline Constant & 1.957 & 0.260 & & 7.538 & 0.000 \\
\hline $\begin{array}{c}\text { Service } \\
\text { Quality } \\
\text { of } \\
\text { Insurance } \\
\text { Company }\end{array}$ & 0.225 & 0.072 & 0.261 & 3.125 & 0.002 \\
\hline $\begin{array}{c}\text { Perceived } \\
\text { Value of } \\
\text { Life } \\
\text { Insurance } \\
\text { Policy }\end{array}$ & 0.306 & 0.083 & 0.347 & 3.669 & 0.000 \\
\hline $\begin{array}{c}\text { Role of } \\
\text { Agent }\end{array}$ & 0.047 & 0.067 & 0.058 & 0.698 & 0.486 \\
\hline
\end{tabular}

Table 7. Summary Hypothesis Testing

\begin{tabular}{|c|c|c|c|}
\hline Hypothesis & Types of Hypothesis & $\mathrm{p}$-value & Decision \\
\hline $\mathrm{H}$ & $\begin{array}{l}\text { Service quality of } \\
\text { insurance company has } \\
\text { significant effect } \\
\text { towards iGeneration } \\
\text { behavior in purchasing } \\
\text { life insurance policy }\end{array}$ & $0.002<0.05$ & Accepted \\
\hline $\mathrm{H} 2$ & $\begin{array}{l}\text { Perceived value of life } \\
\text { insurance policy has } \\
\text { significant effect } \\
\text { towards iGeneration } \\
\text { behavior in purchasing } \\
\text { life insurance policy. }\end{array}$ & $0.000<0.05$ & Accepted \\
\hline $\mathrm{H}_{3} \quad:$ & $\begin{array}{l}\text { Role of agent has } \\
\text { significant effect } \\
\text { towards iGeneration } \\
\text { behavior in purchasing } \\
\text { life insurance policy. }\end{array}$ & $0.486<0.05$ & Rejected \\
\hline
\end{tabular}


Based on Table 6 and Table 7 above, it shows that the result for Perceived Value of Insurance Company variable is 0.000 which is less than 0.05 significant level. Therefore, Perceived Value of Insurance Company variable is significant, thus $\mathrm{H}_{1}$ is accepted. Furthermore, it is explaining that Perceived Value of Insurance Company is the most influential factor among the three independent variables as its Beta value is the highest among the three variables at 0.347 . The second variable is Service Quality of Insurance Company also significant with p-value of 0.002 , is less than 0.05 significant level, which means $\mathrm{H}_{2}$ is accepted and it explains that Service Quality of Insurance Company has some influence on dependent variable. The last variable is Role of Agent with p-value of 0.486 which is more than 0.05 level of significance. Role of Agent variable is not significant and explains that Role of Agent has little or no influence on dependent variable. Therefore, $\mathrm{H}_{3}$ is rejected. This is perhaps Role of Agent has multi collinearity and the questionnaires similarity influence each other, plus most of the respondents that participated in this survey may not have sufficient knowledge about role of agent.

\section{Discussion}

Significance of the findings is interpreted and described in a discussion. The significance is usually already known from the research problem being investigated. Hence, new understanding or fresh insights about the problem are explained, after taking the findings into consideration. It is a practice that discussion is well connected to the introduction in terms of the research questions posed, hypotheses postulated and the literature reviewed.

Based on this first hypothesis, the regression analysis indicates that there is a relationship between service quality of insurance company and iGeneration behavior towards purchasing life insurance policy in Malaysia as the service quality of insurance company variable influenced iGeneration behavior variable. The result of regression between this variable is significant which, the respondents agreed with service quality of insurance company as the second influential factor that motivates iGeneration to purchase life insurance policy. This also shows that insurance company had provided the services that most probably met iGeneration expectation and thus, made their company well known among iGeneration in Malaysia. This finding is consistent with [19] and [24], who propose that both intangible and tangible service quality dimensions are detrimental to influence decision makings of individuals into purchasing life insurance policies. In particular, high quality service offered by the insurance provider will influence the intention of the customers' behavior [16].

For normality, this variable is considered as normally distributed while for validity of questionnaire, all 10 questions are valid for this study and reliable. On the other hand, for the mean on the questionnaire, most respondents agreed with the statement that the premium they pay for life insurance policy is fair and reasonable as compared to the services they get as this statement has the highest mean.

As for hypothesis two, the regression analysis showed a significant relationship between perceived value of life insurance policy and iGeneration behavior towards purchasing life insurance policy in Malaysia. This is where the perceived value of life insurance policy variable influenced iGeneration behavior variable. In fact, from the regression analysis results, it can be seen that the respondents agreed with between perceived value of life insurance policy as the most influential factor that motivates iGeneration to purchase life insurance policy. This is consistent with a recent literature that stated that when consumers perceived more intrinsic and extrinsic value and benefit [6] and [25] on life insurance solutions, they are more likely to purchase the life insurance policy [30]. Furthermore, iGeneration in Malaysia believe that life insurance can give them great benefit which gives benefits not only relating to illness and death but also acts as an investment medium [27].

This variable is considered as normally distributed for Normality Test. As for the reliability and validity of the questionnaire, all 10 questions are valid and reliable for this study. Looking at the highest mean of the perceived value questions, most respondents believe that the life insurance policy could provide benefits to them and lessen their family burden as this statement has the highest mean. This finding is in line with previous study [27] which indicates that perceived value of life insurance policy would increase the intention to purchase life insurance policy significantly.

Lastly for the third hypothesis, the regression analysis indicates that there is no significant relationship between role of agent and iGeneration behavior towards purchasing life insurance policy in Malaysia. Apart from that the role of agent variable, it has low positive correlation towards iGeneration behavior variable. The result of regression between these variables is not significant as the respondents do not agree with the role of agent as the factor that could influence iGeneration in purchasing life insurance policy. This result is contrast with other empirical studies [12], [14] and [24] which, state that most agents have full knowledge or information about life insurance policy that enables the agents to give the correct details and answers to all the questions asked. Besides that, the agents also supposed to help iGeneration to get the cheapest or the best life insurance product prices to be purchase [9] and [13]. However, the iGeneration believed otherwise.

For normality, this variable is considered as normally distributed while for validity of questionnaire, all 10 questions are valid for this study and reliable. In addition, for the mean on the questionnaire, most iGeneration agreed with the statement that dishonesty of an agent make them doubt to purchase life insurance as this statement has the 
highest mean. This statement is supported by literature review [1] that indicates most of iGeneration have trust issue where iGeneration still believed that the agent will take advantage in charging the high premium and keeping the highest commission for themselves. If this situation materialized, the agent will find that he/she will face with difficulty to gain iGeneration's' trust. Meanwhile, the lowest mean was the agent is easy to contact because iGeneration feel that in actual fact the agent is difficult to be contacted. Hence, this finding indicates that the role of an agent has little or no influence on iGeneration behavior in purchasing life insurance policy in Malaysia.

\section{Conclusion}

The fact that perceived value of life insurance policy was found to be the most influential factor that affects iGeneration behavior in purchasing life insurance policy is not surprising in this internet era. As discussed before, iGeneration spend most of their time on the internet and social media, therefore it is not surprising if their decision to purchase life insurance policy is based on information they found in the internet. In contrast, the iGeneration perception towards the role of the insurance agent's methods or approaches of selling insurance traditionally is no longer effective. Perhaps with a good service quality demonstrates by the insurance companies, the iGeneration will consider to purchase the life insurance policy. This is because iGeneration will only be interested and follow products or services that represent their ideals. Since majority of iGeneration are willing to share their info online, thus it is a good opportunity for the insurance companies and their agents to enhance their marketing efforts to capture the potential buyers among the iGeneration via the social media. On top of that, the contribution of insurance companies as a catalyst of financial system in Malaysia, could boost the Malaysian economy in the future. Hence, it is suggested that further research should be conducted among insurance companies in Malaysia to investigate their strategic plans in influencing iGeneration to purchase life insurance policy.

\section{Acknowledgements}

We would like to express our thanks and appreciation to Faculty of Business Management, UiTM Selangor, Puncak Alam campus for awarding the faculty grant with the following project code: 600-IRMI 5/3/DDF (FPP) $(011 / 2019)$ to enable us to proceed with this research.

\section{REFERENCES}

[1] Araujo, M. (2019). Have You Just Bought Life Insurance?
Here's How Much Your Agent Made. The Balance. Available from: https://www.thebalance.com/lifeinsuranceagent-commission-2645804

[2] BNM (2016), Annual Insurance Statistics. Available from:www.bnm.gov.my/index.php?ch=statistic\&pg=statsin surance

[3] Caress, A. (2018). The iGeneration The Challenges and Opportunities Facing a Generation of Digital Natives. Reflection Magazine. available from:https://www.montreat. edu/about/reflection/spring-2018/igeneration/

[4] Chtterjee, S., and Hadi, A.S (2012), Regression Analysis by Example, $\left(5^{\text {th }}\right.$ ed.), Wiley. Carol., K (2019), Agency Theory, Business Essentials Available from: https://www.investope dia.com/terms/a/agencytheory.asp

[5] Crosby, L.A. and Stephens, N. (1987), Effects of relationship marketing on satisfaction, retention, and prices in the life insurance industry, Journal of Marketing Research, 24 (4),404-411.

[6] Dorsch, M., Grove, S., J., \& Darden, W. (2000). Consumer intentions to use a service category. Journal of Service Marketing, 14(2), 92-117.

[7] Fiske, S. T., \& Taylor, S. E. (1991, pg 23). Social cognition (2nd ed.). New York: McGraw-Hill.

[8] Furman, D. M. (2010). The development of corporate image: A historiographic approach to a marketing concept. Corporate Reputation Review, 13(1), 63-75.

[9] Hoover, S. (2016). Long-Term Care Insurance (LTCI): The Good, the Bad, and the Ugly. [Blog] CFA Institute. Available from: https://blogs.cfainstitute.org/investor/2016/ 09/19/the-pros-and-cons-of-long-term-careinsurance/

[10] Jackie L. M. T. (1999) The Effects of Service Quality, Perceived Value and Customer Satisfaction on Behavioral Intentions, Journal of Hospitality \& Leisure Marketing, 6:4, $31-43$,

[11] Jensen, M. 2000. A theory of the firm: Governance, residual claims, and organizational forms. Cambridge, MA: Harvard University Press.

[12] Kaplan Financial Education, (2019), What Does a Life Insurance Agent Do? Available from: https://www.kaplanfi nancial.com/resources/getting-started/what-does-a-life-insu rance-agent-do

[13] Keong, C. (2014). Determinants of Customer Satisfaction In Conventional Insurance Services: The Case Of Malaysia. [online] Eprints.utar.edu.my. Available from: http://eprints. utar.edu.my/1279/1/BF-2014-1100383.pdf

[14] Launstein, H. C. (1959). The agent's responsibility for developing sound insurance programs. Journal of Risk and Insurance (Pre1986), 26(3), 61.

[15] Mollahosseini, A. and Jabbarzadeh, B. (2011), Determination the effect risk, value and knowledge Price intention of buying grey market in Kerman province. Journal of Modern Marketing Research, 1, 1-22.

[16] Njenga, K.P. (2013). Service Quality and Purchase of Life Insurance at Jubilee Insurance Company of Kenya Limited. Master Dissertation. University of Nairobi. Available from http://erepository.uonbi.ac.ke/bitstream/handle/11295/5889 
9/Kinyanjui Service $\% 20$ quality $\% 20$ and $\% 20$ purchase $\% 20$ o $\mathrm{f} \% 201$ ife $\% 20$ insurance $\% 20$ at $\% 20$ jubilee $\% 20$ insurance $\% 20$ company $\% 20$ of $\% 20$ Kenya $\% 20 \% 20$ limited.pdf? sequence $=3$

[17] Pepper., A. and Gore., J. (2015), Behavioral Agency Theory: New Foundations for Theorizing About Executive Compensation, Journal of Management, 41(4), 1045-1068

[18] Perez, S., (2017, March 03). U.S. consumers now spend 5 hours per day on mobile devices. Flurry Analytics. Available from

https://techcrunch.com/2017/03/03/u-s-consumers-now-spe nd5-hours-per-day-on-mobile-devices/

[19] Qureshi, M. N. Z., and Bhatt, J. (2015). An assessment of service quality, customer satisfaction and customer loyalty in life insurance corporation of india with special reference to Srinagar district of Jammu and Kashmir. Pac. Bus. Rev. Int. 7, 60-70.

[20] Rosen, L. D. (2010, Mar 27). Welcome to the iGeneration! Here's how to define the generation born into new millennium technology. Available from https://www.psych ologytoday.com/gb/blog/rewired-the-psychologytechnology /201003/welcome-the-igeneration

[21] Schmidta., K.N and Iyera., K. S. (2015), Online Behaviour of Social Media Participants' and Perception of Trust, Comparing Social Media Brand Community Groups and Associated Organized Marketing Strategies, Procedia Social and Behavioral Sciences. 177, 432 - 439

[22] Schneider, J. (2015). How to Market to the iGeneration. Harvard Business Review. available from: https://hbr.org/2015/05/how-to-market-to-theigeneration

[23] Sekaran, U, and Bougie, R. (2013). Research Methods for Business: A Skill-Building Approach ( $6^{\text {th }}$ ed.), Wiley.

[24] Siddiqui, M. H., \& Sharma, T. G. (2010). Analyzing customer satisfaction with service quality in life insurance services. Journal of Targeting, Measurement and Analysis for Marketing, 18(3-4), 221-238.

[25] Song, M., X. \& Parry, M., E. (1997). The determinants of Japanese new product successes. Journal of Marketing Research, 34(1), 64-76.

[26] Stein, L. (2010). Your retirement nest egg: A goose, egg or a golden goose. School Business Affairs, 76(2), 33-35.

[27] Susanti, A., Darmawan, R., E., \& Ardyan, E. (2017) Enhancing young generation intention to use life insurance in Indonesia. International Journal of Civil Engineering and Technology, 8(8):1141-1154.

[28] Sweeney, J.C.; Soutar, G.N.; Johnson, L.W. (1997), Retail service quality and perceived value, Journal of Retailing and Consumer Services, 4(1), 39-48.

[29] Vahlberg, V. (2013). A Survey of Three Studies About Youth Media Usage. Newspaper Association of America Foundation, [online] pp.9-15. Available from: https:/www.americanpressinstitute.org/wpcontent/uploads/ 2013/09/NIE Fitting into their lives.pdf

[30] Weedige, S., S., Ouyang, H., Yao, G., \& Yaqing, L. (2019). Decision Making in Personal Insurance: Impact of Insurance Literacy. Sustainability. 11(23), 1-24.

[31] Zakaria, Z., Azmi, N., Hassan, N., Salleh, W., Tajuddin, M., Sallem, N. and Noor, J. (2016). The Intention to Purchase Life Insurance: A Case Study of Staff in Public Universities. Procedia Economics and Finance, 37, pp.358-365.

[32] Zeithaml, V.A, Berry, L.L and Parasuraman, A., (1988), Communication and Control Processes in the Delivery of Service Quality, Journal of Marketing, 52(2), 35-48

[33] Zikmund, W.G. (2003) Business Research Methods. 7th Edition, Thomson/ South-Western. 